\title{
Total en bloc spondylectomy and circumspinal decompression for solitary spinal metastasis
}

\author{
K Tomita MD, Y Toribatake MD, N Kawahara MD, H Ohnari, H Kose MD \\ Department of Orthopaedic Surgery, School of Medicine, Kanazawa University, 13-1 \\ Takaramachi, Kanazawa, Ishikawa, 920 Japan.
}

We have developed a new surgical technique, 'total en bloc spondylectomy' (TES), to treat a solitary metastasis in the thoracic or lumbar vertebra. This operation is designed as a local cure for the metastatic site and involves the radical resection of the affected vertebra with a wide margin. The spondylectomy consists of two steps: en bloc laminectomy with posterior spinal instruments for stabilisation (first step) and en bloc corporectomy and replacement using a vertebral prosthesis (second step). TES makes it possible to remove the affected vertebra extracompartmentally with its tumour barrier and accomplishes circumferential decompression of the spinal cord. Before clinical practice, we constructed experimental models using cats to examine spinal cord blood flow (SCBF) after ligation of the nerve roots and circumspinal decompression. The changes of SCBF were negligible, so it was proved that TES on one vertebra has little effect on spinal cord circulation. This method was used in 24 patients. Fourteen of the 18 patients with neurological deficits improved remarkably, and the 23 evaluable cases experienced pain relief. Impending paralysis was prevented in all six patients by this surgical intervention. There has been no recurrence of the local tumour after surgery. After a median follow up period of 14.1 months, 12 patients have survived. These data suggest that TES may have a significant clinical value in the treatment of spinal metastasis.

Keywords: spinal metastasis; spondylectomy; spinal instrumentation.

\section{Introduction}

The ideal surgical treatment of a malignant bone tumour is en bloc resection. However, it is practically impossible in the spine because the spinal cord runs within the spine. The surgical treatments for these patients were nothing more than a partial curettage of the tumour for spinal decompression, which was far from the oncological purpose.

Thus we have developed a surgical technique called 'total en bloc spondylectomy' (TES) to perform an oncological radical resection of the tumour as well as a circumferential decompression of the involved spinal cord. In this paper, we present our procedure for TES, and describe an experimental study to prove the safety of TES on the blood flow and function of the spinal cord.

\section{Surgical indications}

The indications for surgical intervention in patients with a metastatic spinal tumour are neurological deficit, intractable pain, and spinal instability. Additionally, the oncological factors in patient selection for TES include (1) a solitary or localised metastasis, (2) successful treatment of the primary lesion, and (3) a life expectancy of at least 6 months. We prefer TES for the lesion extending throughout the anterior to posterior components of the vertebra.

\section{The surgical technique of total en bloc spondylectomy}

Preoperative angiography and embolisation of the feeder vessels is performed within 3 days of surgery. The surgical procedure 
consists of two steps and will be described for a tumour in the thoracic spine. Most of the procedures are quite similar in the lumbar spine, except for those on rib and pleura.

Step 1. En bloc laminectomy and posterior spinal instrumentation

\section{Exposure of posterior elements}

The patient is in a prone position and the laminae of the affected vertebrae and of the two rostral and caudal levels are exposed. The lower half of the proximal lamina and its inferior articular processes are chiselled off, and the superior facets of the affected vertebra are exposed bilaterally. The transverse processes of the affected vertebra also are exposed bilaterally.

\section{Rib resection and management of} intercostal vessels

The ribs of the affected vertebra are transected $3-4 \mathrm{~cm}$ lateral to the costotransverse joint, and the pleura is bluntly separated from the vertebra. The posterior intercostal artery and its branches are cauterised, divided and mobilised with the pleura.

\section{Pediculotomy and en bloc laminectomy}

A specially manufactured theadwire saw of $0.54 \mathrm{~mm}$ diameter is inserted into the epidural space beneath the lamina through a guide and is pulled out of the intervertebral foramen. The saw is used to divide the pedicle sharply (Fig 1). After

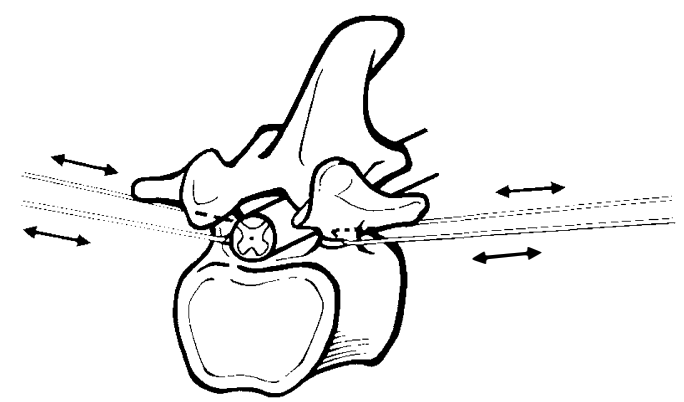

Figure 1 Bilateral pediculotomy during the first stage of TES of T12 is accomplished using a threadwire saw. bilateral pediculotomy, the lamina become mobile. The yellow ligament is divided and the posterior componentsthe lamina, the transverse processes, the superior and inferior intervertebral processes and the spinous process-are removed en bloc.

\section{Posterior spinal instrumentation}

$\mathrm{CD}$ pedicle screws are placed in the two vertebrae rostral and in the two caudal to the affected vertebra, and the rods are contoured and fixed. This CD instrumentation system stabilises the spine whose stability will be completely destroyed by the following procedure.

Step 2. En bloc corporectomy and reconstruction of the spinal column

\section{Extracompartmental exposure of the} vertebral body

The pleura is carefully separated from the anterior longitudinal ligament, and the intercostal artery is mobilised and retracted anteriorly. The intercostal nerve must be preserved or sacrificed. Using extrapleural finger dissection or a vertebral protector, a tunnel is made so that the surgeon's fingertips can touch each other anterior to the vertebra. The pulsation of the aorta will be felt on the back of the left finger. Utmost care must be taken not to injure the azygos vein or the inferior vena cava at this point. The vertebral protector is inserted from both sides to meet at the anterior wall of the vertebra to protect the large vessels. All these procedures are performed outside the tumour margin.

\section{Circumspinal decompression and protection of the spinal cord}

The dura mater and the nerve roots at the level of the affected vertebra are carefully separated from the posterior longitudinal ligament and the vertebral body. If the tumour protrudes into the spinal canal, it should be separated carefully from the dura. Then, a cord protector is inserted between the dura and the vertebra to protect the spinal cord. 


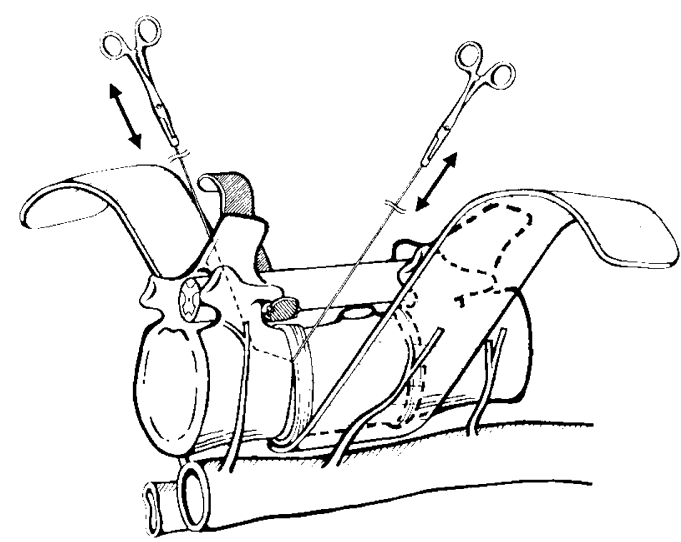

Figure 2 Discotomy rostral and caudal to the affected vertebra using a threadwire saw, followed by corporectomy (b).

\section{Discotomy and en bloc corporectomy} (Fig 2)

Two threadwire saws are placed at the upper and lower intervertebral discs of the affected vertebra and the discs are divided. When the saw gets close to the posterior wall of the vertebra, an assistant should hold the cord protector tightly so that the saw does not injure the cord. Following discotomy, the affected vertebral body is free. Then, it is removed en bloc extracompartmentally. This procedure completes the total en bloc spondylectomy. The surgical field is checked carefully for residual macroscopic tumour tissue, and is irrigated well with a solution containing an anticancer drug (Mitomycin or cis-Platinum).

\section{Insertion of the artificial vertebral body and fixation of spinal instrumentation} Reconstruction of the anterior spinal column is achieved by inserting a ceramic vertebral spacer. The $\mathrm{CD}$ rods are readjusted to fix the prosthesis tightly, and bone allografts are placed around the prosthesis and rods.

\section{Postoperative management}

The patient is allowed to sit up and walk with a trunk cast after 1 week, depending on the neurological status.

\section{Experimental study of total en bloc spondylectomy}

In this TES operation, the blood supply from all around the spinal cord is damaged. Moreover, bilateral nerve roots and accompanying segmental arteries have occasionally to be ligated. Therefore, ischaemic damage to the spinal cord is to be carefully avoided. It has been said that even a single laminectomy reduced the spinal cord blood flow (SCBF) from 22 to $40 \%,{ }^{1}$ but the effect of circumspinal decompression on the SCBF was not examined. Therefore, this study examines the physiological effects of TES on spinal cord circulation in cats.

\section{Methods and materials}

Seventeen cats of either sex, ranging in weight from 2.9 to $4.7 \mathrm{~kg}$ were used in the study. Bradshaw ${ }^{2}$ has observed that all Adamkiewicz arteries in 10 cats enter the medulla with L4 nerve roots. Consequently, we created two experimental groups. In group A $(n=7)$, the L3 nerve roots were ligated, preserving the Adamkiewicz artery, and in group $\mathrm{B}(n=10)$, the L4 nerve roots were ligated, sacrificing the Adamkiewicz artery. All animals were anaesthetised with intraperitoneal pentobarbital sodium $(30 \mathrm{mg} / \mathrm{kg})$ and intubated. The animals received positive-pressure ventilation with a respirator and were maintained on a $\mathrm{N}_{2} \mathrm{O} / \mathrm{O}_{2}$ mixture. A polyethylene cannula was advanced into the midthoracic aorta from a femoral artery to monitor the mean arterial pressure (MAP) and to obtain blood samples for $\mathrm{pCO}_{2}$ and $\mathrm{pO}_{2}$ determination. MAP was kept at the range of $80-120 \mathrm{mmHg}$. Blood gases were kept in the physiological range by adjusting the respiratory rate and the $\mathrm{O}_{2}$ concentration of the inspired gases.

Spinal cord blood flow (SCBF) was measured by the hydrogen clearance method prior to laminectomy as a control, following laminectomy, ligation of the left lumbar nerve roots, ligation of the bilateral lumbar roots, and TES (Fig 3). After each measurement of SCBF, the spinal cord evoked potential was recorded by administering single electric shocks to the upper spinal cord (descending SCEP). All data 
a

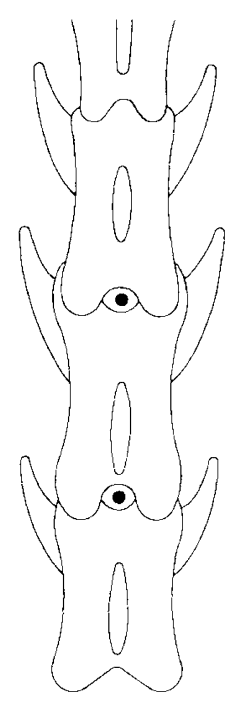

b

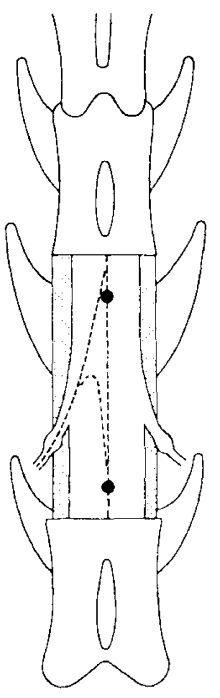

c

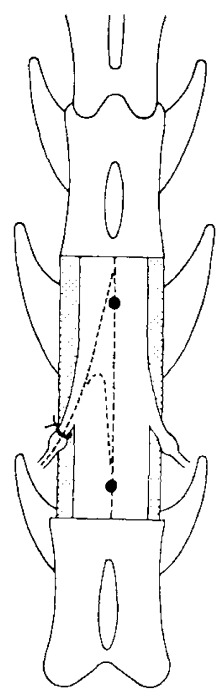

d

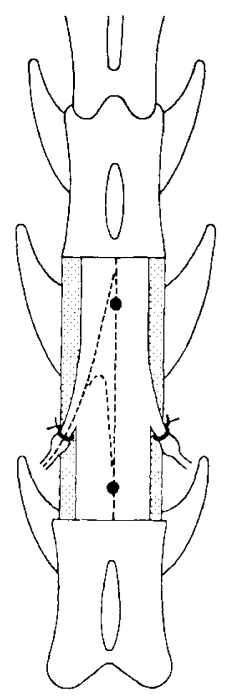

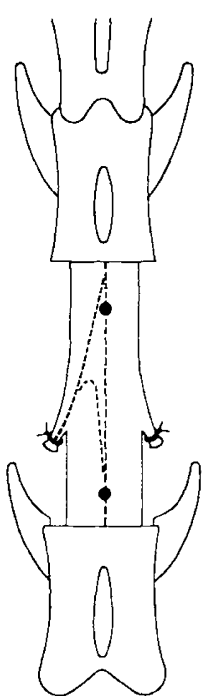

Figure 3 Schematic diagrams of the surgical procedures. (a) Control (before laminectomy); (b) Step 1 (laminectomy); (c) Step 2 (ligation of the left root); (d) Step 3 (ligation of the bilateral roots); (e) Step 4 (total en bloc spondylectomy).

were statistically analysed by the two-way analysis of variance. For illustrative purposes, the data are presented in Figures 4 and 5 as percentage changes in SCBF from control.

\section{Results}

The SCBF decreased significantly following laminectomy (average, $22.1 \%$ ), but circum-

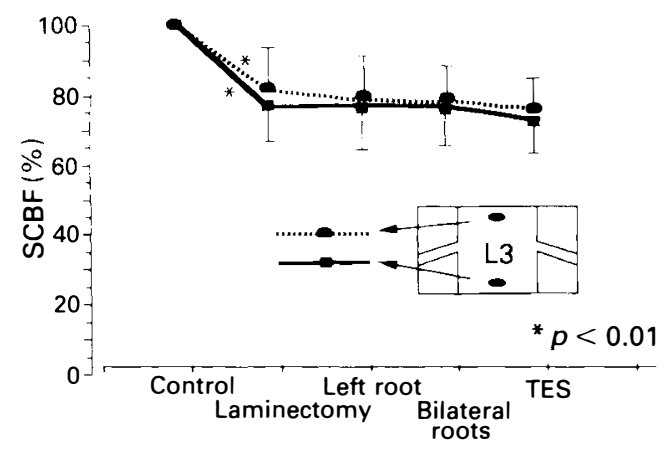

Figure 4 SCBF (\%) in group A preserving the Adamkiewicz artery. Following laminectomy, the SCBF was significantly reduced (by an average of $18.3 \%$ ). However, no significant changes were observed following ligation of the left root, or ligation of bilateral roots and TES.

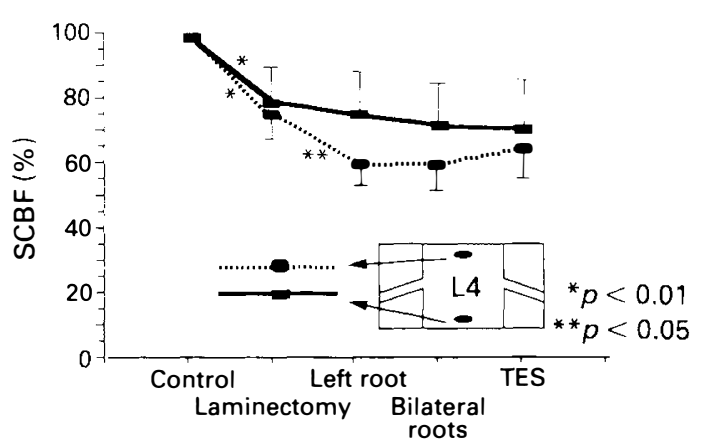

Figure 5 SCBF (\%) in group B sacrificing the Adamkiewicz artery. Following laminectomy, SCBF was significantly reduced (by an average of $25.0 \%$ ). Following ligation of the Adamkiewicz artery, the SCBF was further reduced (by an average of $14.6 \%$ ) to a significant extent. However, no significant changes were observed following ligation of the bilateral roots and TES.

spinal decompression produced no further decrease (Figs 4, 5). The ligation of the Adamkiewicz artery decreased the SCBF by only $19.0 \%$ on average (Fig 5) and caused no conduction disturbance electrophysiologically (Fig 6). The modest reduction in blood flow and lack of demonstrable 


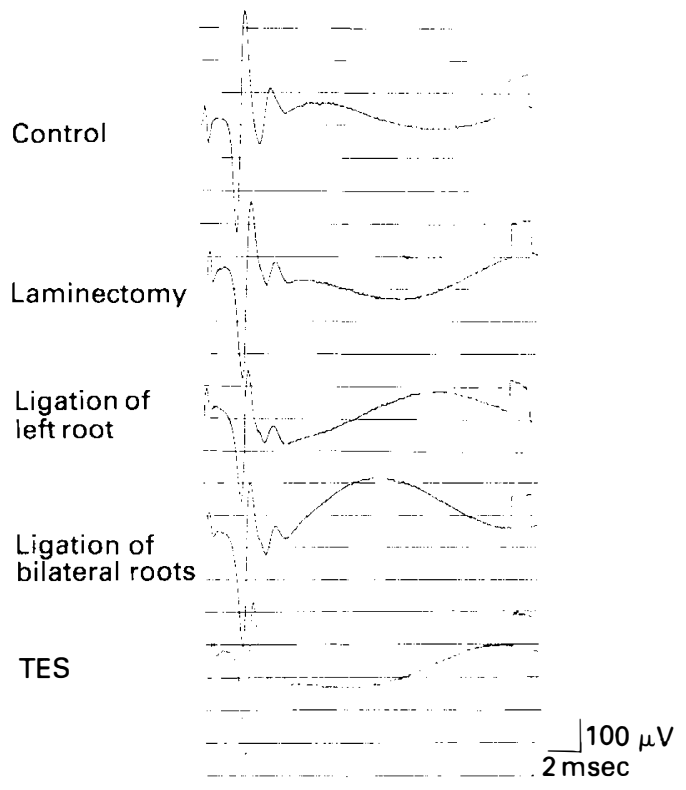

Figure 6 Changes in the descending spinal cord evoked potential (SCEP) at each surgical step. No remarkable changes were observed.

electrophysiological alterations following TES suggest that TES on one vertebra has little effect on spinal cord circulation.

\section{Patients and methods}

Between 1989 and 1993, 24 patients underwent TES at the Kanazawa University Hospital for metastatic tumours of the thoracic (18) or lumbar (6) spine (Table I). There were 16 men and eight women, ranging in age from 19 to 75 years (mean, 58.9 years). Primary malignancies included thyroid cancer (three), lung cancer (four), breast cancer (two), prostate cancer (two), renal cell carcinoma (four), rectal cancer (two), and rhabdomyosarcoma, leiomyosarcoma, cholangiocellular carcinoma, colon cancer, adrenal cancer, multiple myeloma, and hepatocellular carcinoma (one each). Two patients with thoracic lesions had additional lumbar lesions treated by en bloc corporectomy or en bloc laminectomy (cases 3,11 ). Six patients had distant metastases in the liver and/or lungs (cases 4, 6, 7, $13,15,17)$.

The neurological deficit depended on the level of the lesion and the degree of cord compression by tumour or by collapsed cortical bone. The Frankel grading system, supplemented by evaluation of ambulation and urinary continence, was used to assess the neurological outcome. One patient was classified as Frankel grade A, four as grade $\mathrm{B}$, six as grade $\mathrm{C}$, seven as grade $\mathrm{D}$, and six as grade $\mathrm{E}$. Ten patients also had a bladder-bowel dysfunction. The pain response was assessed objectively based on consumption of narcotic analgesics. Twentytwo patients had severe constant pain requiring regular administration of narcotic analgesics. A Harrington rod with segmental sublaminar wiring was used for posterior stabilisation in the first two patients in this series. Subsequently, the CD instrumentation was used in 22 patients. Anterior stabilisation was achieved using an allograft in two patients and a ceramic, hydroxyapatite spacer in the remaining 22 . All patients, except the one who died 3 days after surgery (case 4), were followed up with pain radiographs and $\mathrm{CT}$ scans for the detection of local tumour recurrence.

\section{Results (Table I)}

Twenty-two patients had suffered intractable pain preoperatively. All patients, except one who died 3 days after surgery, experienced permanent partial or complete pain relief following total en bloc spondylectomy. Nineteen patients were pain free, and two required occasional nonnarcotic analgesics. One patient required further surgery because of the displacement of the CD instrument (case 5).

No patient's neurological condition worsened following total en bloc spondylectomy. Impending paralysis was prevented in all six patients with Frankel grade E, and all seven patients with Frankel grade D recovered fully. Of the 11 patients who were unable to walk preoperatively, seven (64\%) regained the ability to ambulate after surgery. Of the 10 patients with loss of bladder control, eight patients $(80 \%)$ were continent postoperatively. Our previous experience, and that of others, is that piecemeal resection of a metastatic spinal tumour is associated with a high incidence of local recurrence within 6 months of surgery, with 
Table I Demographic details of patients undergoing TES

\begin{tabular}{|c|c|c|c|c|c|c|c|c|c|c|}
\hline Case & Age/Sex & Primary & $\begin{array}{l}\text { Level of } \\
\text { surgery }\end{array}$ & Reconstruction & Pain & $\begin{array}{l}\text { Impending } \\
\text { paralysis }\end{array}$ & $\begin{array}{l}\text { Frankel } \\
\text { grade }\end{array}$ & $\begin{array}{l}\text { Bladder } \\
\text { function }\end{array}$ & Survival & Comments \\
\hline 1 & $19 / \mathrm{M}$ & $\begin{array}{l}\text { Rhabdomyo- } \\
\text { sarcoma }\end{array}$ & $\mathrm{T} 7$ & $\begin{array}{l}\text { Harrington }+ \\
\quad \text { CS }\end{array}$ & Improved & & $\mathrm{C}-\mathrm{E}$ & Improved & $\begin{array}{l}25 \text { months } \\
\text { (dead) }\end{array}$ & \\
\hline 2 & $53 / \mathrm{M}$ & Thyroid cancer & T9-10 & $\begin{array}{l}\text { Harrington }+ \\
\text { allograft }\end{array}$ & Improved & & $\mathrm{A}-\mathrm{A}$ & No recovery & $\begin{array}{l}12 \text { months } \\
\text { (dead) }\end{array}$ & \\
\hline 3 & $58 / \mathrm{M}$ & Leiomyosarcoma & $\mathrm{T} 3$ & $\mathrm{CD}+\mathrm{CS}$ & Improved & & $\mathrm{C}-\mathrm{D}$ & & $\begin{array}{l}37 \text { months } \\
\text { (surviving) }\end{array}$ & $\begin{array}{l}\text { L3, en bloc } \\
\text { corporectomy }\end{array}$ \\
\hline 4 & $64 / F$ & Thyroid cancer & T5-6 & $\mathrm{CD}+\mathrm{CS}$ & Ineligible & & $\mathrm{C}-\mathrm{C}$ & & $\begin{array}{l}3 \text { days (dead } \\
\text { of DIC) }\end{array}$ & $\begin{array}{l}\text { Prior anterior } \\
\text { stabilisation }\end{array}$ \\
\hline 5 & $63 / F$ & Lung cancer & T9 & $\mathrm{CD}+\mathrm{CS}$ & Improved & Prevented & $E-E$ & & $\begin{array}{l}34 \text { months } \\
\text { (surviving) }\end{array}$ & $\begin{array}{l}\text { Displacement } \\
\text { of } C D\end{array}$ \\
\hline 6 & $65 / \mathrm{M}$ & Prostate cancer & $\mathrm{T} 4-5$ & $C D+$ allograft & Improved & & $D-E$ & Improved & 8 months (dead) & \\
\hline 7 & $54 / \mathrm{M}$ & Lung cancer & $\mathrm{T} 3,4$ & $\mathrm{CD}+\mathrm{CS}$ & Improved & & $\mathrm{C}-\mathrm{C}$ & Improved & 3 months (dead) & \\
\hline 8 & $58 / \mathrm{M}$ & Rectal cancer & $\mathrm{T} 3,4$ & $C D+C S$ & Improved & & $D-E$ & Improved & $\begin{array}{l}11 \text { months } \\
\text { (dead) }\end{array}$ & \\
\hline 9 & $67 / \mathrm{M}$ & $\begin{array}{l}\text { Cholangiocellular } \\
\text { carcinoma }\end{array}$ & $\mathrm{T} 2$ & $\mathrm{CD}+\mathrm{CS}$ & Improved & & $C-D$ & Improved & 9 months (dead) & \\
\hline 10 & $67 / F$ & $\begin{array}{l}\text { Renal cell } \\
\text { carcinoma }\end{array}$ & L3 & $\mathrm{CD}+\mathrm{CS}$ & None & & $\mathrm{D}-\mathrm{E}$ & & $\begin{array}{l}32 \text { months } \\
\text { (surviving) }\end{array}$ & $\begin{array}{l}\text { Anterior strut- } \\
\text { allograft } \\
\text { posterior } \\
\text { H-allograft }\end{array}$ \\
\hline 11 & $52 / \mathrm{F}$ & Breast cancer & $\mathrm{T} 12$ & $\begin{array}{c}\mathrm{CD}+\mathrm{CS}+ \\
\text { cancellous } \\
\text { autograft }\end{array}$ & Improved & Prevented & $E-E$ & & $\begin{array}{l}31 \text { months } \\
\text { (surviving) }\end{array}$ & $\begin{array}{l}\text { L2, en bloc } \\
\text { laminectomy }\end{array}$ \\
\hline 12 & $62 / \mathrm{M}$ & Colon cancer & $\mathrm{L} 2$ & $\mathrm{CD}+\mathrm{CS}$ & Improved & & $\mathrm{C}-\mathrm{D}$ & & 7 months (dead) & \\
\hline 13 & $56 / \mathrm{F}$ & Adrenal cancer & $\mathrm{T} 7$ & $\mathrm{CD}+\mathrm{CS}$ & Improved & & $\mathrm{B}-\mathrm{D}$ & Improved & 6 months (dead) & \\
\hline
\end{tabular}




\begin{tabular}{|c|c|c|c|c|c|c|c|c|c|c|}
\hline Case & Age/Sex & Primary & $\begin{array}{l}\text { Level of } \\
\text { surgery }\end{array}$ & Reconstruction & Pain & $\begin{array}{l}\text { Impending } \\
\text { paralysis }\end{array}$ & $\begin{array}{l}\text { Frankel } \\
\text { grade }\end{array}$ & $\begin{array}{l}\text { Bladder } \\
\text { function }\end{array}$ & Survival & Comments \\
\hline 14 & $55 / \mathrm{F}$ & Rectal cancer & $\mathrm{T} 1$ & $\mathrm{CD}+\mathrm{CS}$ & Improved & Prevented & $\mathrm{E}-\mathrm{E}$ & & $\begin{array}{l}22 \text { months } \\
\text { (surviving) }\end{array}$ & \\
\hline 15 & $67 / \mathbf{M}$ & Lung cancer & T9 & $\mathrm{CD}+\mathrm{CS}$ & Improved & & B-B & No recovery & 3 months (dead) & \\
\hline 16 & $67 / \mathrm{M}$ & Prostate cancer & T11 & $\mathrm{CD}+\mathrm{CS}$ & None & Prevented & $E-E$ & & $\begin{array}{l}19 \text { months } \\
\text { (dead) }\end{array}$ & \\
\hline 17 & $67 / \mathrm{M}$ & $\begin{array}{l}\text { Hepatocellular } \\
\text { carcinoma }\end{array}$ & $\mathrm{T} 10$ & $\mathrm{CD}+\mathrm{CS}$ & Improved & & $B-D$ & Improved & 4 months (dead) & \\
\hline 18 & $75 / \mathrm{M}$ & $\begin{array}{l}\text { Renal cell } \\
\text { carcinoma }\end{array}$ & L3 & $\mathrm{CD}+\mathrm{CS}$ & Improved & & $\mathrm{D}-\mathrm{E}$ & & $\begin{array}{l}16 \text { months } \\
\text { (surviving) }\end{array}$ & \\
\hline 19 & $55 / \mathrm{F}$ & Thyroid cancer & L2 & $\mathrm{CD}+\mathrm{CS}$ & Improved & & $\mathrm{D}-\mathrm{E}$ & & $\begin{array}{l}15 \text { months } \\
\text { (surviving) }\end{array}$ & $\begin{array}{l}\text { Posterior } \\
\text { H-allograft }\end{array}$ \\
\hline 20 & $50 / \mathrm{F}$ & Breast cancer & $\mathrm{T} 8$ & $\mathrm{CD}+\mathrm{CS}$ & Improved & Prevented & $E-E$ & & $\begin{array}{l}15 \text { months } \\
\text { (surviving) }\end{array}$ & \\
\hline 21 & $73 / \mathrm{M}$ & Multiple myeloma & $\mathrm{T} 11$ & $\begin{array}{c}\mathrm{CD}+\mathrm{CS}+ \\
\text { cancellous } \\
\text { autograft }\end{array}$ & Improved & & $B-D$ & Improved & $\begin{array}{l}8 \text { months } \\
\quad \text { (surviving) }\end{array}$ & \\
\hline 22 & $52 / \mathrm{M}$ & $\begin{array}{l}\text { Renal cell } \\
\text { carcinoma }\end{array}$ & $\mathrm{L} 2$ & $\mathrm{CD}+\mathrm{CS}$ & Improved & & $\mathrm{D}-\mathrm{E}$ & & 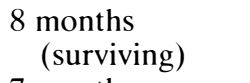 & $\begin{array}{l}\text { Posterior } \\
\text { H-allograft }\end{array}$ \\
\hline 23 & $56 / \mathrm{M}$ & Lung cancer & $\mathrm{T} 10$ & $\mathrm{CD}+\mathrm{CS}$ & Improved & Prevented & $E-E$ & & 7 months & \\
\hline 24 & $57 / \mathrm{M}$ & $\begin{array}{l}\text { Renal cell } \\
\text { carcinoma }\end{array}$ & L4 & $\mathrm{CD}+\mathrm{CS}$ & Improved & & $\mathrm{D}-\mathrm{E}$ & & 6 months & $\begin{array}{l}\text { Posterior } \\
\text { H-allograft }\end{array}$ \\
\hline
\end{tabular}

$\mathrm{CD}=$ Cotrel-Dubsset instrumentation; $\mathrm{CS}=$ ceramic spacer; $\mathrm{DIC}=$ disseminated intravascular coagulation. 
recurrent pain and with progressive neurological deficit. The lack of local recurrence following en bloc resection in this series stands in striking contrast (Fig 7).

The time of operation ranged from 5.5 to 10.2 hours (mean, 7.2 hours). Blood loss was extremely variable, ranging from 590 to $2410 \mathrm{ml}$ (mean, $1525 \mathrm{ml}$ ). Blood loss was higher in surgery involving long spinal decompression and fusion, probably owing to the multiple vertebral levels requiring decompression, the large area of exposure, and the prolonged time of operation. Insufficient or unsuccessful embolisation also was a major contributor to operative blood loss.

A major complication occurred in two patients. One was a 64 year old woman with thyroid cancer who had T5-6 metastases (case 4). She had undergone an anterior spinal decompression at the same level in another hospital and had developed a local recurrence. She died of disseminated intravascular coagulation (DIC) following TES 3 days after surgery. The other patient, a 63 year old woman with a metastasis at T9 from lung cancer (case 5), underwent TES using the $\mathrm{CD}$ instrumentation system. Two months after surgery, the pedicle screws became loose and were displaced. The instrument was replaced using hooks, and the back pain resolved. Three patients complained of transient intercostal neuralgia and sensory disturbances related to ligation and cutting of the intercostal nerves. These minor complaints improved within 3 weeks after surgery.

The final follow up of the 12 surviving patients ranged from 6 to 37 months (average, 14.1 months). Twelve patients died from disseminated metastatic disease, with a mean survival of 8.8 months (range, 3-25 months). There were no deaths from unrelated causes. No patient developed local recurrence, and no patient suffered either neurological deterioration or instrumentation failure owing to tumour progression.

\section{Case report (case 19)}

A 55 year old woman had undergone a thyroidectomy for thyroid cancer. Three

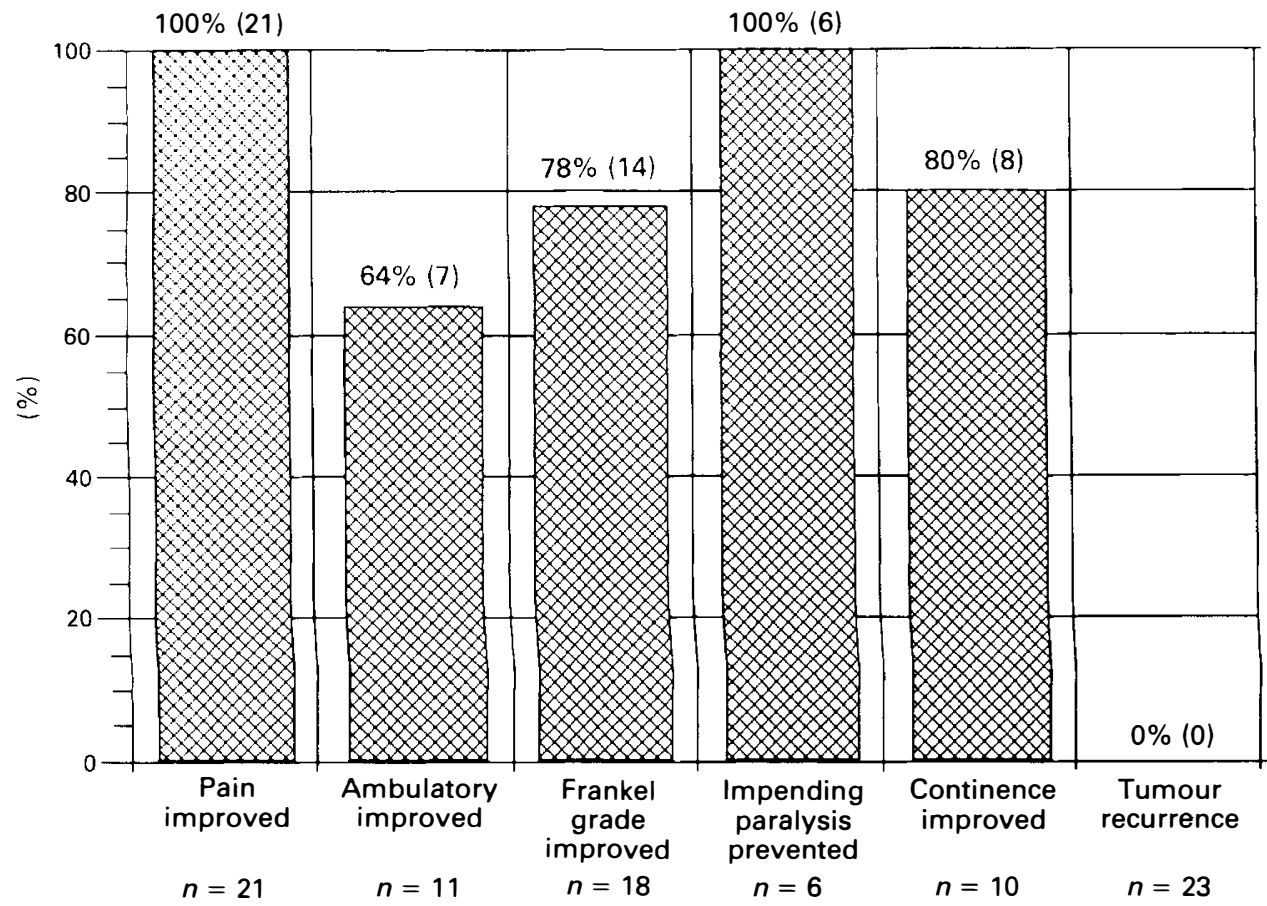

Figure 7 Bar graph showing results of the total en bloc spondylectomy. 
years later, she developed a severe low back pain, with numbness and weakness of her legs. A solitary metastasis at the L2 level was found. TES was performed, and symptoms improved remarkably from Frankel grade $D$ to $E$. As a result she has been completely free from pain and been stable for the last 15 months.

a

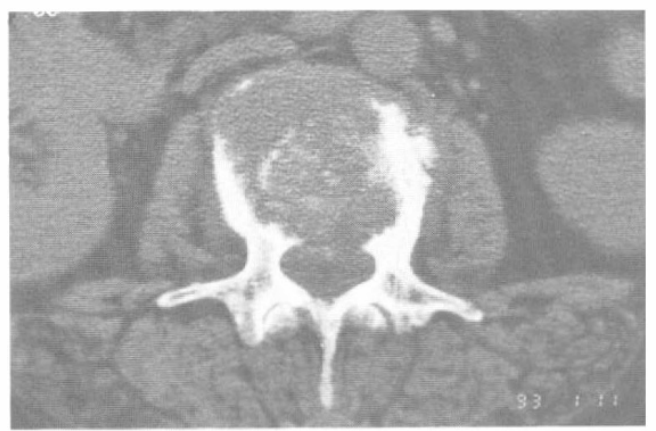

b

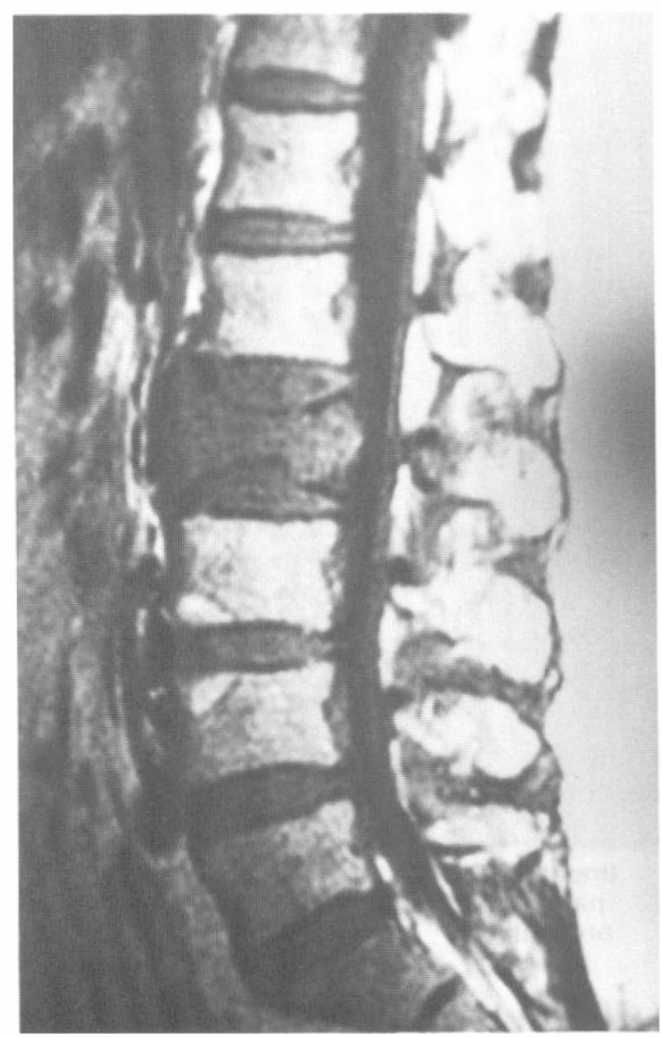

\section{Discussion}

In the past, patients with spinal metastasis were thought to be in the terminal stage. Even if surgery was performed in some patients, the purpose was only to decompress the spinal cord or stabilise the spine,

c

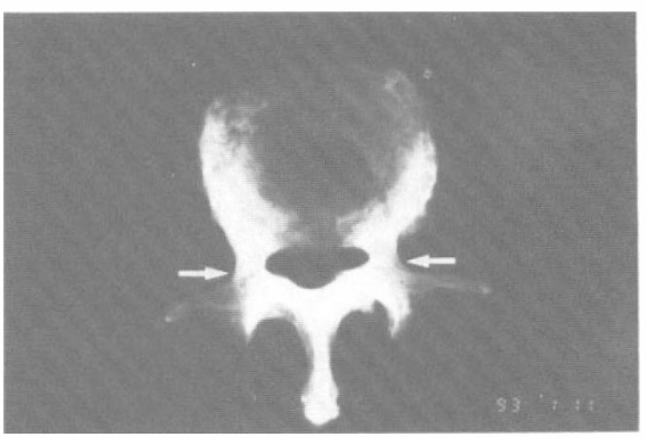

d

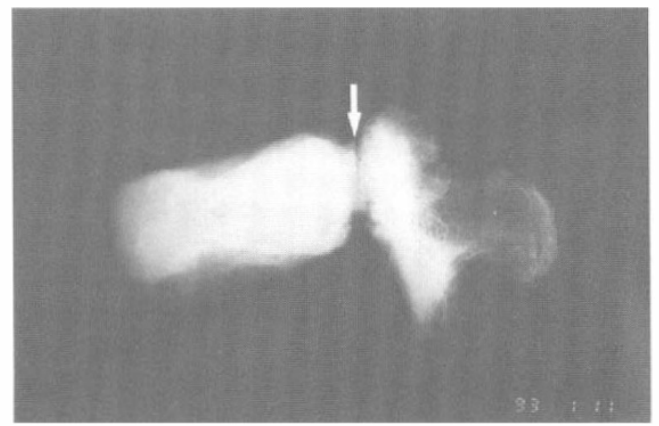

Figure 8 A 55 year old woman treated with total en bloc spondylectomy for solitary L2 metastasis from thyroid cancer (case 19). (a) CT scan at the L2 level showing the corpus and paraspinal area affected by a tumour with a pathological fracture (stage IV). (b) MRI showing the tumour of the corpus of L2 bulging into the spinal canal. (c), (d) Radiograph of the resected L2 vertebra (horizontal and sagittal view). Arrow: cut lesion using the threadwire saw. (e), (f) Radiograph after TES. The spine was reconstructed with $C D$ instrumentation system and a ceramic spacer augmented by an allograft was used as the prosthesis for the vertebral body. 


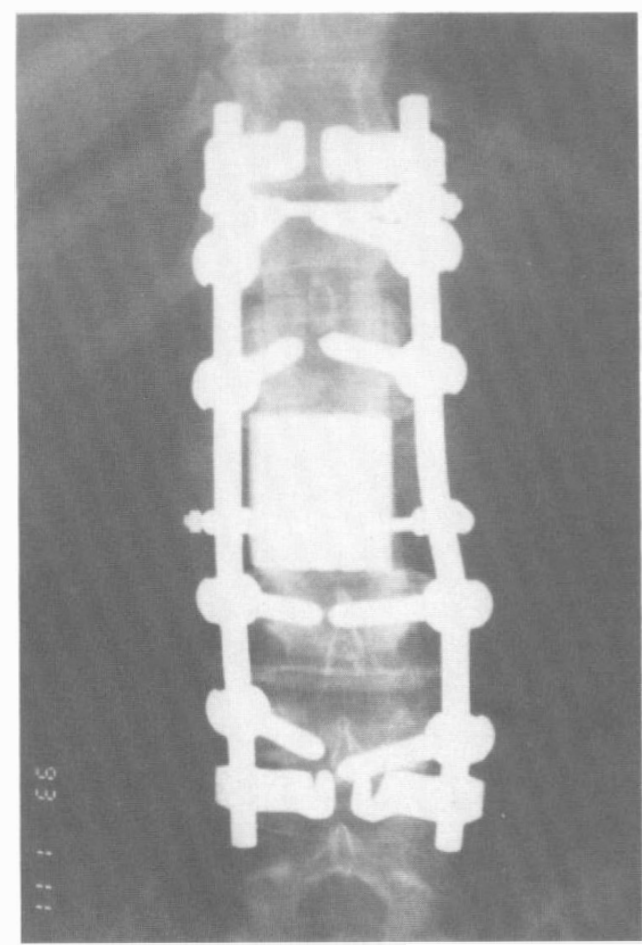

Figure 8e and $\mathbf{f}$ Caption on previous page.

so the results have been disappointing because of insufficient cord decompression and local tumour recurrence.

On the other hand, we have successfully performed circumspinal decompression for patients with severe myelopathy due to ossification of the posterior longitudinal ligament combined with ossification of the yellow ligament in the thoracic spine and have followed the concept that the spinal cord should be completely decompressed circumferentially. The results have been quite satisfactory. ${ }^{3}$ Applying this experience, we developed total en bloc spondylectomy (TES), a radical surgery for spinal metastasis to perform en bloc resection of the affected vertebra and circumspinal decompression.

The first total spondylectomy was performed by Liévre et $a l^{4}$ by piecemeal resection of a giant cell tumour in the fourth lumbar vertebra. Subsequently, Stener et f

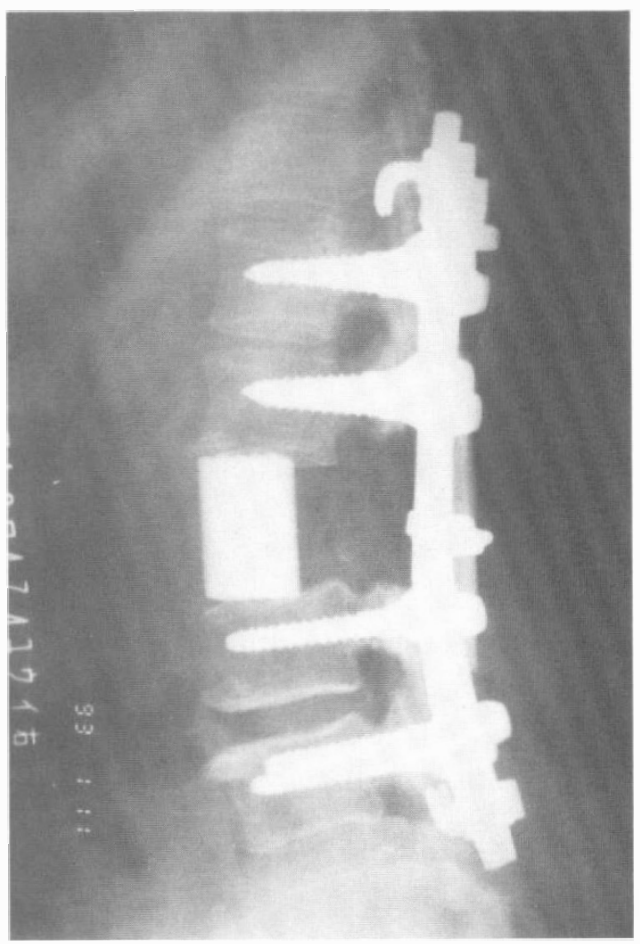

$a l^{5}$, Roy-Camille et $a l^{6}$ and Sundaresan et $a l^{7}$ reported cases of total spondylectomy, but all of their procedures for tumour removal were based on intracapsular curettage or piecemeal resection. Of course, the surgery must be intralesional at the cutting edge of the vertebra to preserve the function of the spinal cord. Therefore, we chose the pedicle to obtain the minimal cutting edge to minimise tumour cell contamination. When the affected vertebra is cut at the pedicle, the posterior portion (lamina) and the anterior portion (vertebral body) are resected en bloc, respectively. At the same time, this procedure is regarded as an oncological subcompartmental resection.

In this TES operation, blood supply from all around the spinal cord is damaged. Moreover, bilateral nerve roots and accompanying segmental arteries occasionally need to be ligated. Therefore, ischaemic damage to the spinal cord is a danger. 
The experimental cat model of TES showed that the SCBF was reduced by $22.1 \%$ following laminectomy but no further reduction was seen after TES. The ligation of the Adamkiewicz artery reduced the SCBF by only $19.0 \%$, and there was no electrophysiological conduction disturbance. As a result, TES is thought to have little effect on SCBF. Therefore, we believe that TES is the most reliable procedure for oncological prophylaxis available today.

\section{Conclusions}

A new surgical technique, 'total en bloc spondylectomy' for the treatment of spinal metastasis has been introduced. Our experimental study proved that it does not adversely affect the spinal cord blood flow, and our results of a study in 24 selected patients suggest that it is a valuable operation. We believe this operation has a significant clinical value in the treatment of spinal metastasis.

\section{References}

1 Anderson DK, Nicolosi GR, Means ED, Hartley LE (1987) Effect of laminectomy on spinal cord blood flow. J Neurosurg 48: 232-238.

2 Bradshaw P (1958) Arteries of the spinal cord in the cat. J Neurosurg Psychiatry 21: 284-289.

3 Tomita K, Kawahara N, Baba H, Kikuchi Y, Nishimura H (1990) Circumspinal decompression for thoracic myelopathy due to combined ossification of the posterior longitudinal ligament and the yellow ligament. Spine 15: 1114-1120.

4 Lievre JA, Darcy M, Pradat P, Camus JP, Bénichou C, Attali P et al (1968) Tumeur a cellues géantes du rachis lombaire, spondylectomie totale en deux temps. Rev Rhum 35: 125-130 (in French).

5 Stener B (1971) Total spondylectomy in chondrosarcoma arising from the seventh thoracic vertebra. J Bone Joint Surg 53(B): 288-295.

6 Roy-Camille R, Saillant G, Bisserié M, Judet TH, Hautefort E, Mamoudy P (1981) Resection vertebrale totale dans la chirurgie tumorale au niveau du rachis dorsal par voie posterieure pure. Rev Chir Orthop 67: 421-430.

7 Sundaresan N, Digiacinto GV, Krol G, Hughes JE (1989) Spondylectomy for malignant tumor of the spine. J Clin Oncol 7: 1485-1491. 